\title{
Tyranny of the pain score question after surgery
}

The views expressed in this editorial are those of the author and do not necessarily reflect the position of the Canadian Medical Association or its subsidiaries.

ome surgeons are concerned that their efforts for the patient to have a good experience of surgery may be subverted in the post-anesthesia care unit (PACU). Once the patient is awake and extubated, I usually assist in their transfer to the stretcher. While they are being covered with a warm blanket, I ask if they enjoyed the operation, confirming that it went well. My purpose is to counter the effect of the question that will dominate their experience of the PACU: "What is your pain, out of 10 ?" I don't know of any business that greets their customers with a query about the level of their dissatisfaction. Imagine then, my reply when I found myself waking up from an anesthetic, with a strange face looking down on me, asking loudly the dreaded question.

Only recently did I discover the reason why the "pain out of 10 " question is so resistant to modification. In 2000, lobbying by the American Pain Society (APS) succeeded in having the pain score included in the initial postoperative check demanded by the Joint Commission for Accreditation of Healthcare Organizations, which certifies hospitals in the United States. ${ }^{1}$ Physicians specializing in pain management were concerned that pain was undertreated; their campaign conflated chronic pain with postoperative pain. The APS said that the new, stronger opiates would deal with the pain without a risk of addiction, and we moved from meperidine and codeine to fentanyl and oxycodone to treat the same conditions, without an apparent improvement. ${ }^{2}$

The Canadian Pain Society (CPS) is continuing this campaign. Activists lobbied the Senate in 2004 for the first week of November to be designated National Pain Awareness Week. The examples used to convince the politicians all concerned chronic conditions. ${ }^{3}$ Purdue Pharma (Canada) promoted National Pain Awareness Week with a news release that highlighted chronic pain. ${ }^{4}$ The news release referred to a CPS fact sheet. ${ }^{5}$ It is not clear who wrote the "Pain in Canada" fact sheet. Its first four bullets highlight dissatisfaction with postoperative surgical care, including the following claims: "Although we have the knowledge and technology, Canadians are left in pain after surgery, even in our top hospitals"; "Only $30 \%$ of ordered medication is given, $50 \%$ of patients are left in moderate to severe pain after surgery and the situation is not improving"; and "Acute postoperative pain is followed by persistent pain in $10 \%-50 \%$ of individuals after common surgical procedures (groin hernia repair, breast and thoracic surgery)."

Drug companies in the United States and Canada have used national pain societies, nursing organizations and regulators to promote their message that opiates are underprescribed. Despite a string of lawsuits regarding their marketing practices that have resulted in fines and settlements totalling more than $\$ 600$ million, ${ }^{6}$ companies continue to profit from long-acting super-opioids, such as OxyContin, to the tune of approximately $\$ 30$ billion a year. Dr. David Kessler, who was the US Food and Drug Administration (FDA) commissioner when OxyContin was approved, now believes its approval was a mistake. ${ }^{7}$ It is with trepidation, therefore, that we welcome their approval of sublingual sufentanil, a drug with 500 times the potency of morphine.

In the current opioid crisis, many examples of dependence are believed to have started with the intended short-term use of opioids after surgery or trauma. In addition, unused prescribed opioids are considered to be a significant source of inappropriate access. Surgeons are not unaware of the problem. Several studies have looked at ways to limit opioid use after surgery. Mitchell and colleagues ${ }^{8}$ of Halifax have shown that a nonsteroidal antiinflammatory drug (NSAID) is equivalent to codeine when used with acetaminophen after general surgery. Hartford and colleagues ${ }^{9}$ of London encouraged patients to take acetaminophen and an NSAID after outpatient surgery, giving them a prescription for a short course of tramadol, to be filled for breakthrough pain. Less than $30 \%$ of the patients filled the prescription, and many of them used only a few pills. These studies strongly suggest that overprescription of opioids after surgery is a problem.

There are lessons available to us from the military. The road to mental readiness program of the Canadian Armed Forces is designed to build resilience against operational stress by anticipating the conditions of deployment and controlling expectations. ${ }^{10} \mathrm{We}$ could modify this program to prepare our patients for surgery. Total absence of postoperative pain is not a realistic expectation. Rather, understanding expected discomfort and knowing countermeasures will permit patients to recover with minimal use of opioids. Unnecessary restrictions regarding exercise and lifting give the impression of fragility and cause anxiety. Patients can be 
reassured if they understand what is unexpected pain after surgery and have easy access to return to hospital.

I had a benign tumour expertly removed from the spinal canal, requiring a spinal fusion. The anesthesia, surgery and nursing teams were so good that I used the experience to learn how to improve care that I give. I was determined to be a patient and not use medical knowledge or access for special favour. I had not anticipated that I would have to rate my pain out of 10 within moments of waking up from the operation. I considered the matter quickly and broke my vow not to use my knowledge of postoperative care. I answered "zero." Acetaminophen and ibuprofen were sufficient to allow a speedy and enjoyable recovery.

\section{Vivian C. McAlister, MB \\ Coeditor, Canadian fournal of Surgery}

Competing interests: None declared.

DOI: $10.1503 /$ cjs. 017418

\section{References}

1. Phillips DM. JCAHO pain management standards are unveiled. Joint Commission on Accreditation of Healthcare Organizations. $7 A M A$. 2000;284:428-9.

2. Gounder C. Who is responsible for the pain-pill epidemic? The New Yorker. 2013 Nov. 8. Available: www.newyorker.com/business/currency/ who-is-responsible-for-the-pain-pill-epidemic (accessed 2018 Nov. 12).
3. Government of Canada. Debates of the Senate. 2004;142:243-4. Available: https://sencanada.ca/Content/SEN/Chamber/381/Debates/ pdf/013db_2004-11-04-e.pdf (accessed 2018 Nov. 12)

4. Purdue Pharma. National pain awareness week - message from Dr Tom Koutsavlis, vice president, research development, Purdue Pharma (Canada). Available: http://purdue.ca/en/2017/11/06/national-pain -awareness-week-message-from-dr-tom-koutsavlis-vice-president -research-development-purdue-pharma-canada/ (accessed 2018 Nov. 12).

5. Canadian Pain Society. Pain is poorly managed in Canada. Available: https://c.ymcdn.com/sites/www.canadianpainsociety.ca/resource/ resmgr/Docs/pain_fact_sheet_en.pdf (accessed 2018 Nov. 12).

6. Lopez G. The growing number of lawsuits against opioid companies, explained. Vox 2018 May 15. Available: www.vox.com/policy-and -politics/2017/6/7/15724054/opioid-epidemic-lawsuits-purdue-oxycontin (accessed 2018 Nov 12).

7. Former FDA head: Opioid epidemic one of "great mistakes of modern medicine." CBS News 2016 May 9. Available: www.cbsnews.com/news/ former-fda-head-doctor-david-kessler-opioid-epidemic-one-of-great -mistakes-of-modern-medicine/ (accessed 2018 Nov 12).

8. Mitchell A, van Zanten SV, Inglis K, et al. A randomized controlled trial comparing acetaminophen plus ibuprofen versus acetaminophenplus codeine plus caffeine after outpatient general surgery. $7 \mathrm{Am}$ Coll Surg 2008; 206: 472-9.

9. Hartford LB, Van Koughnett JAM, Murphy PB, et al. Standardization of Outpatient Procedure (STOP) Narcotics: a prospective non-inferiority study to reduce opioid use in outpatient general surgical procedures. $\mathcal{F}$ Am Coll Surg. 2018 Sep 25. pii: S1072-7515(18)32038-6. doi: 10.1016/j. jamcollsurg.2018.09.008. [Epub ahead of print].

10. Government of Canada. National Defence and the Canadian Armed Forces. The Road to Mental Readiness (R2MR) program. Available: www.forces.gc.ca/en/caf-community-health-services-r2mr/index.page? (accessed 2018 Nov. 12).

\section{La tyrannie de la question sur le score de douleur postopératoire}

Les opinions exprimées dans cet éditorial sont celles de l'auteur et ne représentent pas nécessairement celles de l'Association médicale canadienne ou ses filiales.

ertains chirurgiens s'inquiètent que leurs efforts pour que leurs patients aient une expérience chirurgicale positive soient anéantis à la salle de réveil. Une fois le patient éveillé et extubé, je participe habituellement à son transfert sur la civière. Pendant qu'on étend sur lui une couverture chaude, je lui demande si l'intervention s'est bien déroulée pour lui, en lui confirmant que tout a bien été. Mon but est d'annuler l'effet de la question qui dominera son expérience en salle de réveil : «Sur une échelle de 1 à 10 , où se situe votre douleur? $\gg$ Il ne viendrait à personne du milieu des affaires d'accueillir des clients en les interrogeant sur leur degré d'insatisfaction. Imaginez alors ma réponse lorsque je me suis réveillé après une anesthésie, un visage étranger penché sur moi qui me posait à voix haute la question fatidique.
Je n'ai découvert que récemment pourquoi la question sur « le score de douleur sur une échelle de 1 à $10 »$ a la vie si dure. En 2000, les pressions exercées par l'American Pain Society (APS) ont réussi à faire inclure le score de douleur dans la liste de vérification postopératoire initiale demandée par la commission mixte pour l'agrément des établissements de santé qui décernent leur certificat aux hôpitaux américains ${ }^{1}$. Les médecins qui se spécialisent en gestion de la douleur s'inquiétaient que la douleur soit trop peu traitée; leur campagne a gommé les distinctions entre douleur chronique et douleur postopératoire. L'APS a affirmé que les nouveaux opiacés plus puissants allaient soulager la douleur sans risque de dépendance et nous sommes ainsi passés de la mépéridine à la codéine, puis au fentanyl et à l'oxycodone pour traiter les mêmes problèmes et ce, sans amélioration apparente ${ }^{2}$. 